\title{
ANALISIS KEUNGGULAN BERSAING NISSAN DI INDONESIA
}

\author{
Lim Sanny \\ Jurusan Manajemen, Fakultas Ekonomi dan Bisnis, Universitas Bina Nusantara, \\ Jln. K.H. Syahdan No. 9, Palmerah, Jakarta Barat 11480 \\ lsanny@binus.ac.id
}

\begin{abstract}
Automotive sales in Indonesia picked up sharply in 2010, and increase of prices does not lower the demand for automotive products. The large population of Indonesia and the low level of car ownership in the country suggest there is a lot of potential for expansion in the automotive industry. The aim of this research is to observe Nissan's strategy in Indonesia to gain a spot in the top 10 of the best automotive seller in Indonesia. This research uses primary data with forecasting with monthly index to forecast the demand and to detect the selling target plans in 2010. Then, with combined porter five forces to determine the competitive strategy in the last 5 years.
\end{abstract}

Keywords: automotive industry, competitiveness, excellence, porter five forces method

\begin{abstract}
ABSTRAK
Penjualan otomotif di Indonesia tahun 2010 ini mengalami banyak peningkatan, terlihat dari kenaikan harga tidak mempengaruhi terhadap permintaan otomotif. Banyaknya jumlah penduduk di Indonesia dan rendahnya tingkat kepemilikan mobil menjadi salah satu alasan untuk industri otomotif berkembang. Tujuan penelitian ini untuk melihat strategi yang digunakan oleh Nissan untuk masuk ke 10 besar penjualan otomotif terlaris di Indonesia. Metode penelitian yang digunakan adalah pengolahan data primer dengan menggunakan metode forecasting dengan menggunakan data indeks untuk meramalkan permintaan di tahun 2010 serta untuk memprediksi apakah target penjualan di tahun 2010 dapat tercapai. Selain itu, metode porter five forces untuk melihat strategi keunggulan bersaing Nissan selama 5 tahun terakhir ini.
\end{abstract}

Kata kunci: industri otomotif, competitiveness, keunggulan, metode porter five forces 


\section{PENDAHULUAN}

Saat ini, sebagian besar masyarakat Indonesia mengeluhkan tingginya harga beras sehingga mereka kesulitan untuk memenuhi kebutuhan hidupnya sehari-hari. Di sisi lain, penjualan otomotif meningkat. Terlihat dari melonjaknya penjualan mobil pada bulan Januari lalu, yang merupakan angka pasar awal tahun tertinggi sejak tahun 2006, yang merupakan tahun keterpurukan industri otomotif setelah kesuksesannya di tahun 2005. Penjualan mobil di Indonesia mengalami masa kejayaan pada tahun 2005, tetapi selanjutnya di tahun 2006 terjadi penurunan yang cukup besar, yaitu sebesar 45\% dibandingkan tahun 2005. Hal tersebut dikarenakan kenaikan harga BBM dan suku bunga yang tinggi. Hal tersebut membuat membuat produsen menunda hingga tahun 2007 untuk memproduksi model baru (Gaikindo, 2009). Akhirnya di akhir tahun 2007 muncul beberapa varian baru, meskipun tidak sebanyak di tahun 2005. Persaingan yang makin ketat di antara merek mobil dengan porsi pertumbuhan yang tidak terlalu besar sehingga konsumen diberi banyak pilihan. Tahun 2007 merupakan titik awal untuk bangkitnya industri otomotif, dan persaingan tersebut terlihat sangat besar di kelas low Sport Utility Vehicle (SUV) dengan kapasitas mesin 1500-2000 cc. Pasar SUV banyak diminati karena dapat mengangkut banyak orang. Hal tersebut cocok dengan karakteristik masyarakat Indonesia yang memiliki anggota keluarga berjumlah besar (Indonesia Autos Report, 2009).

Tabel 1 Penjualan Otomotif di Indonesia tahun 2005 - 2009

\begin{tabular}{cccccc}
\hline \multirow{5}{*}{ Bulan } & \multicolumn{5}{c}{ Penjualan tahun } \\
\cline { 2 - 6 } & $\mathbf{2 0 0 5}$ & $\mathbf{2 0 0 6}$ & $\mathbf{2 0 0 7}$ & $\mathbf{2 0 0 8}$ & $\mathbf{2 0 0 9}$ \\
\hline Januari & 45,479 & 26,622 & 26,824 & 41,114 & 31,557 \\
Februari & 45,722 & 25,957 & 23,645 & 47,176 & 34,370 \\
Maret & 52,733 & 26,833 & 33,860 & 46,293 & 33,824 \\
April & 51,239 & 22,577 & 35,207 & 51,309 & 34,299 \\
Mei & 51,239 & 23,079 & 38,309 & 50,373 & 35,412 \\
Juni & 49,378 & 24,566 & 39,396 & 53,989 & 39,388 \\
Juli & 49,409 & 21,891 & 38,307 & 60,352 & 41,599 \\
Agustus & 50,629 & 28,066 & 41,359 & 58,231 & 47,678 \\
September & 44,042 & 34,162 & 40,834 & 54,550 & 37,166 \\
Oktober & 35,112 & 20,752 & 31,069 & 54,727 & 52,030 \\
November & 26,069 & 33,222 & 45,613 & 46,050 & 48,322 \\
Desember & 32,866 & 31,177 & 38,918 & 39,610 & 47,903 \\
\hline TOTAL & 533,917 & 318,904 & 433,341 & 603,774 & 483,548 \\
\hline
\end{tabular}

Sumber: Gaikindo (2010)

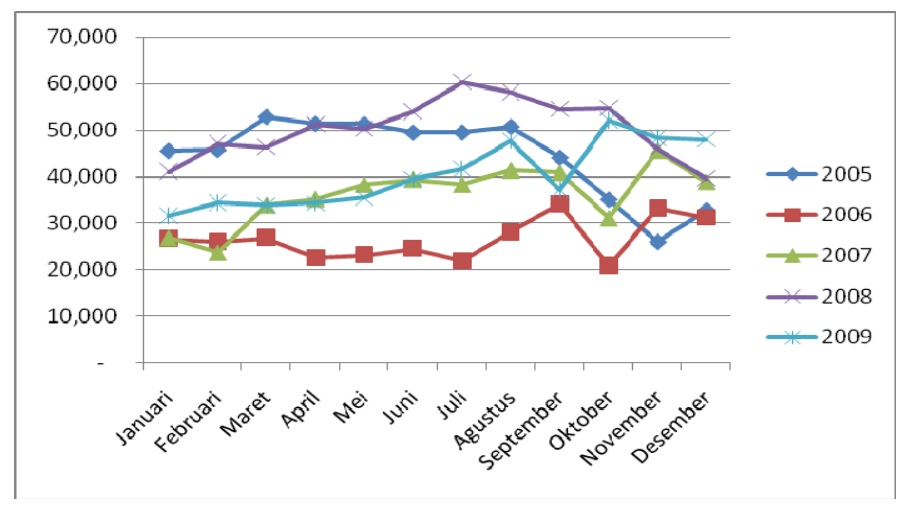

Dari data tersebut terlihat terjadi penurunan penjualan yang cukup signifikan pada tahun 2006, lalu berangsur membaik dari tahun 2007 hingga tahun 2008 dan kembali terjadi penurunan di tahun 2009. 
Berdasarkan data dari Agen Tunggal Pemegang Merek (ATPM) dalam majalah otomotif, Maret 2010, penjualan pada bulan Januari mencapai 53.653 unit. Sebagai perbandingan penjualan pada bulan Januari 2006 adalah sebesar 26.622 unit, Januari 2007 sebesar 26.830 unit, Januari sebesar 200841.378 unit, dan Januari tahun lalu 31.642 unit. Bila dibandingkan dengan Januari tahun lalu, penjualan pada tahun ini melonjak sangat signifikan, yaitu 69,7\%. Pencapaian Januari 2010 juga mengalahkan rekor penjualan tertinggi pada 2009 sebesar 52.226 unit pada Oktober. Meningkatnya penjualan Januari memperlihatkan bahwa tren positif penjualan mobil yang terjadi sejak pertengahan 2009 terus berlanjut. Padahal, biasanya penjualan kendaraan roda empat di awal tahun tidak terlalu tinggi dan baru meningkat pada bulan ketiga. Umumnya, berdasarkan siklus penjualan tahunan di Indonesia, pasar mobil di awal tahun cenderung melemah. Artinya, jumlah penjualan di sebelas bulan selanjutnya memiliki potensi yang cukup besar, untuk bisa lebih tinggi dari Januari setiap tahunnya. Faktor pendukung terjadinya penguatan pasar, kondisi perekonomian global juga mulai berangsur pulih menyusul aksi negara maju mencairkan likuiditas ke pasar. Harga komoditas unggulan seperti minyak sawit, batu bara, dan hasil perkebunan lain ikut menguat sehingga meningkat daya beli konsumen Indonesia (oto.detik.com, 2010).

Tabel 2 Penjualan Otomotif di Indonesia dari tahun 2005 - 2009 per Merek

\begin{tabular}{|c|c|c|c|c|c|c|}
\hline No. & Brand & 2005 & 2006 & 2007 & 2008 & 2009 \\
\hline 1 & Toyota & 182,765 & 123,703 & 150,631 & 211,909 & 186,687 \\
\hline 2 & Dihatsu & 48,762 & 33,021 & 51,957 & 78,041 & 77,513 \\
\hline 3 & Mitsubishi & 89,158 & 47,023 & 61,547 & 87,524 & 61,735 \\
\hline 4 & Suzuki & 87,274 & 44,760 & 58,095 & 73,067 & 44,689 \\
\hline 5 & Honda & 53,750 & 30,000 & 40,000 & 52,500 & 39,570 \\
\hline 6 & Nissan & 10,551 & 4,006 & 19,030 & 31,879 & 21,440 \\
\hline 7 & Isuzu & 25,010 & 16,605 & 18,270 & 25,325 & 15,236 \\
\hline 8 & Hino & 6,145 & 4,193 & 8,224 & 14,227 & 11,390 \\
\hline 9 & Ford & 5,727 & 3,515 & 6,405 & 7,999 & 6,348 \\
\hline 10 & Mercedez Benz & 2,443 & 914 & 2,022 & 2,872 & 3,450 \\
\hline 11 & KIA & 8,668 & 3,852 & 4,039 & 3,880 & 3,195 \\
\hline 12 & Hyundai & 6,391 & 3,003 & 4,020 & 3,800 & 2,667 \\
\hline 13 & Chevrolet & 2,085 & 825 & 1,396 & 2,657 & 2,612 \\
\hline 14 & Proton & - & 305 & 1,584 & 1,089 & 2,150 \\
\hline 15 & Mazda & 652 & 203 & 1,336 & 2,241 & 1,542 \\
\hline 16 & UD Nissan Diesel & 1,867 & 1,380 & 2,115 & 2,391 & 1,298 \\
\hline 17 & BMW & 1,257 & 600 & 1,000 & 720 & 901 \\
\hline 18 & Chery & - & 269 & 759 & 853 & 407 \\
\hline 19 & Lexus & - & - & 46 & 241 & 235 \\
\hline 20 & Volkswagen & 228 & 150 & 208 & 200 & 176 \\
\hline 21 & Audi & 120 & 90 & 110 & 112 & 110 \\
\hline 22 & Peugeot & 486 & 118 & 85 & 59 & 44 \\
\hline 23 & Jaguar & 61 & 27 & 32 & 39 & 35 \\
\hline 24 & Subaru & - & 24 & 38 & 26 & 34 \\
\hline 25 & Land Rover & 85 & 54 & 77 & 52 & 32 \\
\hline 26 & Foton & - & - & - & - & 27 \\
\hline 27 & Volvo & 143 & 69 & 60 & 62 & 25 \\
\hline 28 & Ssangyong & 1 & 6 & 5 & 1 & - \\
\hline 29 & Renault (PC) & 49 & 19 & 8 & 4 & - \\
\hline \multirow[t]{2}{*}{30} & Timor & 239 & 170 & 242 & 4 & - \\
\hline & Domestic Market & 533,917 & 318,904 & 433,341 & 603,774 & 483,548 \\
\hline
\end{tabular}

Dari tabel tersebut, terlihat peningkatan yang sangat besar terjadi pada Nissan di tahun 2007. Padahal di tahun 2006 terjadi penurunan sebesar 62\% jika dibandingkan dengan penjualannya di tahun 2005 sebesar 10,551 unit. Penjualan tahun 2007 sebesar 19,030 unit, angka tersebut meningkat 375\%, selanjutnya penjualan meningkat lagi tahun 2008 sebesar 67,52\%, dan terjadi penurunan di tahun 2009 sebesar 32,75\% jika dibandingkan dengan total penjualan mobil di Indonesia, penurunan di tahun 2006 sebesar 40,27\% dan di tahun 2007 terjadi kenaikan 35,88\% lalu di tahun 2008 naik 39,33\% dan di tahun 2009 turun 19,91\%. Penurunan penjualan nisan tahun 2006 lebih besar dari penurunan penjualan mobil rata-rata, sedangkan peningkatan di tahun 2007 dan 2008 pun lebih besar dari 
peningkatan penjualan mobil rata-rata, begitu pula dengan penurunan di tahun 2009. Hal tersebut terlihat penjualan mobil Nissan di Indonesia terjadi peningkatan penurunan yang cukup drastis selama 5 tahun terakhir ini. Dari data bulan Januari 2010 ini penjualan Nissan livina di tahun 2010 menduduki posisi 6 tertinggi dalam urutan mobil terlaris, yaitu sebanyak 1.543 unit.

Berikut daftar mobil terlaris di bulan Januari 2010, yaitu Toyota Avanza sebanyak 10.218 unit, Daihatsu Xenia 5.071 unit, Toyota Kijang Innova 4.193 unit, Honda Jazz 2.275 unit, Toyota Rush 1.623 unit, Nissan Livina 1.543 unit, Suzuki APV 1.332 unit, Mitsubishi Pajero Sport 1.215 unit, Toyota Yaris 1.195 unit, dan Honda Freed 1.010 unit (Sumber: Syubhan Akib - detikOto, http://oto.detik.com/read/2010/02/17/104945/1301158/648/10-mobil-terlaris-Januari-2010).

Manajemen strategis dapat didefinisikan sebagai seni dan ilmu untuk memformulasi, mengimplementasi, dan mengevaluasi keputusan lintas fungsi yang memungkinkan organisasi dapat mencapai tujuannya. Proses manajemen strategis terdiri atas 3 tahap, yaitu formulasi strategi, implementasi strategi, dan evaluasi strategi. Formulasi strategi termasuk mengembangkan visi dan misi, mengidentifikasi peluang dan ancaman eksternal perusahaan, menentukan kekuatan dan kelemahan internal, menetapkan tujuan jangka panjang, merumuskan altenatif strategi, dan memilih strategi tertentu yang akan dilaksanakan.

Implementasi strategi mensyaratkan perusahaan untuk menetapkan tujuan tahunan, membuat kebijakan, memotivasi karyawan, dan mengalokasikan sumber daya sehingga strategi yang telah diformulasikan dapat dijalankan. Sedangkan tahapan evaluasi strategi adalah tahap final dalam manajemen strategis. Manajemen strategis adalah tentang mendapatkan dan mempertahankan keunggulan kompetitif. Untuk mencapai keunggulan kompetitif yang berkelanjutan haruslah secara terus menerus beradaptasi dengan tren dan kejadian eksternal serta kemampuan, kompetensi, dan sumber daya internal dan dengan secara efektif memformulasikan, mengimplementasi, dan mengevaluasi strategi yang mengambil keuntungan dari faktor-faktor tersebut. Menurut Porter, persaingan suatu industri dapat dilihat sebagai kombinasi atas 5 kekuatan, yaitu persaingan antar perusahaan sejenis, kemungkinan masuknya pesaing baru, potensi pengembangan produk substitusi, kekuatan tawar-menawar penjual/pemasok, dan kekuatan tawar-menawar pembeli/konsumen.

Persaingan antar perusahaan sejenis biasanya merupakan kekuatan terbesar dalam lima kekuatan kompetitif. Strategi yang dijalankan oleh suatu perusahaan dapat berhasil hanya jika mereka memberikan keunggulan kompetitif dibanding strategi yang dijalankan perusahaan pesaing. Perubahan strategi oleh suatu perusahaan mungkin akan mendapat serangan balasan seperti menurunkan harga, meningkatkan kualitas, menambah feature, menyediakan jasa, memperpanjang garansi, dan meningkatkan iklan. Intensitas persaingan diantara perusahaan sejenis yang bersaing cenderungmeningkat karena jumlah pesaing semakin bertambah, karena pesaing semakin seragam dalam hal ukuran dan kemampuan karena permintaan untuk produk industri menurun, dan arena pemotongan harga menjadi semakin umum. Persaingan juga meningkat ketika pelanggan dapat berpindah merek dengan mudah, ketika hambatan untuk meninggalkan pasar tinggi, ketika biaya tetap tinggi, ketika hambatan untuk meninggalkan pasar tinggi, ketika biaya tetap tinggi, ketika produk mudah rusak, ketika perusahaan pesaing berbeda dalam hal strategi, tempat mereka berasal, dan budaya serta ketika merger dan akuisisi menjadi umum dalam suatu industri.

Ketika perusahaan baru dapat dengan mudah masuk ke dalam industri tertentu, intensitas persaingan antar perusahaan meningkat. Tetapi, hambatan untuk masuk, dapat mencakup kebutuhan untuk mencapai skala ekononomi dengan cepat, kebutuhan untuk mendapatkan teknologi dan pengetahuan khusus, kurangnya pengalaman, tingginya kesetiaan pelanggan, kuatnya preferensi merek, besarnya kebutuhan akan modal, kurangnya jalur distribusi yang memadai, peraturan pemerintah, tariff, kurangnya akses terhadap bahan mentah, kepemilikan paten, lokasi yang kurang menguntungkan, serangan balasan dari perusahaan yang sudah mapan, dan potensi kejenuhan pasar. 
Dalam banyak industri, perusahaan bersaing dekat dengan produsen produk substitusi dalam industri yang berbeda. Tekanan kompetisi yang berasal dari produk substitusi meningkat sejalan dengan menurunnya harga relatif dari produk subsititusi dan sejalan dengan biaya konsumen untuk beralih ke produk lain menurun. Cara terbaik untuk mengukur kekuatan kompetitif produk substitusi adalah dengan memantau pangsa pasar yang didapat oleh produk-produk tersebut, juga dengan memantau rencana perusahaan untuk meningkatkan kapasitas dan penetrasi pasar.

Kekuatan tawar-menawar pemasok mempengaruhi intensitas persaingan dalam suatu industry, khususnya ketika ada sejumlah besar pemasok, ketika hanya ada sedikit barang substitusi yang cukup bagus, atau ketika biaya untuk mengganti bahan baku sangat mahal. Seringkali kepentingan yang dicari oleh pemasok dan produsen adalah saling memberikan harga yang masuk akal, memperbaiki kualitas, mengembangkan jasa baru, pengiriman just in time, dan mengurangi biaya persediaan. Dengan demikian, memperbaiki profitabilitas jangka panjang untuk semua pihak.

Ketika konsumen terkonsentrasi atau besar jumlahnya, atau membeli dalam jumlah besar, kekuatan kuatan tawar menawar mereka menjadi kekuatan utama yang mempengaruhi intensitas persaingan dalam suatu industri. Perusahaan pesaing mungkin menawarkan garansi yang lebih panjang atau jasa khusus untuk mendapatkan kesetiaan pelanggan ketika kekuatan tawar-menawar konsumen cukup besar. Kekuatan tawar-menawar konsumen juga lebih tinggi ketika yang dibeli adalah produk standar atau tidak terdiferensiasi. Ketika kondisi seperti ini, pembeli/konsumen seringkali dapat bernegosiasi tentang harga jual, cakupan garansi, dan paket aksesori hingga ke tingkat yang lebih tinggi (David, 2009).

\section{METODE PENELITIAN}

Data yang digunakan adalah data sekunder. Penelitian dilakukan dengan mengumpulkan data sekunder, dan juga dilakukan wawancara dengan pihak Nissan untuk mengetahui strategi yang dilakukan oleh Nissan Indonesia dari tahun 2005 hingga 2010 ini, melihat perkembangan industri otomotif ini tidak besar, tetapi Nissan dapat meningkatkan pangsa pasar yang cukup besar dilihat dari tahun 2006 hingga 2010 ini. Pengolahan data sekunder dengan metode forecasting dengan data indeks untuk tahun 2010 untuk memprediksi penjualan di tahun 2010. Digunakan data per bulan untuk memprediksikan penjualan di tahun 2010 dengan data indeks bulanan, karena dari data tahun 2005 hingga 2009 terlihat penjualan per bulan tidak sama, ada kecenderungan dibulan-bulan tertentu penjualan meningkat, tetapi sebaliknya ada beberapa bulan yang mempunyai kecenderungan penjualan sedikit. Oleh karena itu, perlunya dibuat forecasting dengan menggunakan indeks bulanan sehingga forecasting akan lebih akurat. Selanjutnya, dari penjualan aktual bulan Januari hingga maret 2010, dapat diprediksi total penjualan atau target yang dapat dicapai di tahun 2010 ini. Setelah itu, dilakukan analisis evaluasi strategi dengan five forces Porter untuk melihat keunggulan kompetitif produk Nissan dari tahun ke tahun.

\section{HASIL DAN PEMBAHASAN}

Dari hasil penjualan bulan Januari 2010 sebanyak 53.653 unit dan di bulan Februari sebanyak 54.115 unit. Jika dilihat dari tingginya penjualan bulan Januari dan Februari , maka target penjualan di tahun 2010 sebanyak 650.000 unit dapat tercapai, bahkan tidak mustahil penjualan di tahun 2010 ini akan mencapai angka 750.000 unit kendaraan. Hal tersebut terlihat di indeks bulan Januari, indeks tersebut dihitung dengan menggunakan rumus: 
Penjualan rata-rata 2005 - 2009 dihitung per bulan, jadi untuk bulan Januari, penjualan bulan Januari selama 5 tahun, mulai dari 2005 hingga 2009 dijumlahkan, lalu dibagi 5.

Sedangkan penjualan bulanan rata-rata adalah jumlah dari penjualan rata-rata dibagi 12 bulan. Dari indeks bulan Januari, yaitu sebesar 0,86757 artinya penjualan bulan Januari adalah sebesar 0,86757 dari rata-rata penjualan per bulan. Jadi jika dilakukan peramalan dengan target 650.000 unit yang harus terjual, artinya di bulan Januari 2010 target tersebut sudah tercapai karena penjualan aktual di Januari 2010 sebesar 53.654 unit padahal targetnya hanya sebesar 46,993 unit saja. Jika target penjualan dinaikkan menjadi 750,000 unit, ada kemungkinan akan tercapai karena penjualan bulan Januari mencapai angka yang cukup tinggi, yaitu 53.654 unit, yang merupakan angka tertinggi sejak 5 tahun terakhir ini. Jika dilihat dari angka indeks, terlihat pula kecenderungan penjualan mobil di bulan Januari hingga April masih lebih sedikit. Setelah itu, penjualan mobil akan mulai meningkat di bulan Mei, dan terus meningkat hingga puncaknya di bulan Agustus, lalu akan meningkat kembali di bulan November. Puncak penjualan terjadi di bulan Agustus karena biasanya peningkatan harga mobil terjadi di bulan September sehingga konsumen akan segera membeli kendaraan sebelum harga tersebut naik. Dari data bulan Januari dan Februari 2010, terlihat di tahun 2010 ini merupakan tahun kejayaan industri otomotif di Indonesia karena tahun ini sudah dapat dipastikan akan mencapai penjualan tertinggi, bahkan penjualan di Indonesia selama tahun 2010 ini merupakan penjualan tertinggi di ASEAN (Pugliese, 2010).

Tabel 3 Penjualan Otomotif dan Forecasting di Indonesia

\begin{tabular}{|c|c|c|c|c|c|c|c|c|c|c|}
\hline \multirow[b]{2}{*}{ Bulan } & \multicolumn{5}{|c|}{ Penjualan tahun } & \multirow{2}{*}{$\begin{array}{l}\text { Penj.rata2 } \\
\text { 2005-2009 }\end{array}$} & \multirow{2}{*}{$\begin{array}{l}\text { Penj. } \\
\text { Blnan } \\
\text { Rata2 } \\
\end{array}$} & \multirow[b]{2}{*}{ Indeks } & \multicolumn{2}{|c|}{ Forecasting 2010} \\
\hline & 2005 & 2006 & 2007 & 2008 & 2009 & & & & 650,000 & 750,000 \\
\hline Januari & 45,479 & 26,622 & 26,824 & 41,114 & 31,557 & 34,319 & 39,558 & 0.86757 & 46,993 & 54,223 \\
\hline Februari & 45,722 & 25,957 & 23,645 & 47,176 & 34,370 & 35,374 & 39,558 & 0.89423 & 48,437 & 55,889 \\
\hline Maret & 52,733 & 26,833 & 33,860 & 46,293 & 33,824 & 38,709 & 39,558 & 0.97853 & 53,003 & 61,158 \\
\hline April & 51,239 & 22,577 & 35,207 & 51,309 & 34,299 & 38,926 & 39,558 & 0.98403 & 53,301 & 61,502 \\
\hline Mei & 51,239 & 23,079 & 38,309 & 50,373 & 35,412 & 39,682 & 39,558 & 1.00314 & 54,337 & 62,696 \\
\hline Juni & 49,378 & 24,566 & 39,396 & 53,989 & 39,388 & 41,343 & 39,558 & 1.04513 & 56,611 & 65,321 \\
\hline Juli & 49,409 & 21,891 & 38,307 & 60,352 & 41,599 & 42,312 & 39,558 & 1.06961 & 57,937 & 66,850 \\
\hline Agustus & 50,629 & 28,066 & 41,359 & 58,231 & 47,678 & 45,193 & 39,558 & 1.14244 & 61,882 & 71,402 \\
\hline September & 44,042 & 34,162 & 40,834 & 54,550 & 37,166 & 42,151 & 39,558 & 1.06554 & 57,717 & 66,596 \\
\hline Oktober & 35,112 & 20,752 & 31,069 & 54,727 & 52,030 & 38,738 & 39,558 & 0.97927 & 53,044 & 61,204 \\
\hline November & 26,069 & 33,222 & 45,613 & 46,050 & 48,322 & 39,855 & 39,558 & 1.00751 & 54,574 & 62,969 \\
\hline Desember & 32,866 & 31,177 & 38,918 & 39,610 & 47,903 & 38,095 & 39,558 & 0.96301 & 52,163 & 60,188 \\
\hline
\end{tabular}

Sumber: Gaikindo, data diolah (2010)

\section{Persaingan Antar Perusahaan Sejenis}

Jika dilihat dari total pangsa pasar di Indonesia, Nissan menguasai 1.98\% pangsa pasar mobil di Indonesia tahun 2005, lalu tahun 2006 sebesar 1.26\%, 2007 sebesar 4.4\%, 2008 sebesar 5.28\%, lalu 2009 sebesar 4.43\%. Hal ini cukup baik jika dibandingkan dengan leader otomotif Indonesia, yaitu Toyota yang menguasai 34.2\% di tahun 2005, tahun 2006 sebesar 38.8\%, tahun 2007 sebesar 34.8\%, tahun 2008 sebesar 35.1\%, dan tahun 2009 sebesar 38.6\%. Berikut adalah tabel pangsa pasar yang dari Toyota yang merupakan leader dalam industri otomotif di Indonesia, sedangkan Honda dan Isuzu adalah merek kompetitor utama Nissan. 
Tabel 4 Pangsa Pasar Industri Toyota di Indonesia

\begin{tabular}{lccccc}
\hline & $\mathbf{2 0 0 5}$ & $\mathbf{2 0 0 6}$ & $\mathbf{2 0 0 7}$ & $\mathbf{2 0 0 8}$ & $\mathbf{2 0 0 9}$ \\
\hline Nissan & $1.98 \%$ & $1.26 \%$ & $4.39 \%$ & $5.28 \%$ & $4.43 \%$ \\
Toyota & $34.23 \%$ & $38.79 \%$ & $34.76 \%$ & $35.10 \%$ & $38.61 \%$ \\
Honda & $10.07 \%$ & $9.41 \%$ & $9.23 \%$ & $8.70 \%$ & $8.18 \%$ \\
Isuzu & $4.68 \%$ & $5.21 \%$ & $4.22 \%$ & $4.19 \%$ & $3.15 \%$ \\
\hline
\end{tabular}

Di tahun 2010 ini Nisssan menargetkan pangsa pasarnya mencapai 6\%. Berdasarkan penjualan di bulan Januari dan Februari 2010, terlihat target ini dapat tercapai karena penjualan Januari dan Februari sudah melampaui target penjualan.

\section{Kemungkinan Masuk Pesaing Baru}

Kemungkinan masuknya pesaing baru sangat mungkin terjadi, mengingat banyak sekali merek dalam industri otomotif di Indonesia, dan mengingat Indonesia mempunyai pangsa pasar yang cukup besar dengan tingkat kepemilikan mobilnya masih rendah dibandingkan negara-negara lain. Untuk mengantisipasinya, Nissan selalu menguatkan brand nya sebagai 3 besar perusahaan mobil dari jepang di Indonesia, setelah Toyota dan Honda. Selain itu, strategi yang dilakukan oleh Nissan dengan melakukan antisipasi akan masuknya pesaing baru dengan memproduksi berbagai macam merek. Untuk kelas MPV, kehadiran Nissan Grand Livina cukup baik dalam menguasai pasar. Nissan Grand Livina merupakan model kunci bagi PT Nissan Motor Indonesia (NMI) untuk mencapai target penjualannya. Grand Livina memberikan kontribusi 60\% dari total penjualan. PT Nissan Motor Indonesia mencatat penjualan sebanyak 1.048 unit sepanjang Indonesia International Motor Show (IIMS) 2010, 23 Juli hingga 1 Agustus lalu di Jakarta. Penjualan terbesar diperoleh dari Livina Family (Grand Livina, Livina X-Gear, Livina XR, dan Grand Livina Star Highway), yaitu 69\%. Sedangkan model-model lain, yaitu Serena 18\%, X-Trail 11\%, dan model CBU (Teana, Frontier dan Navara) 2\%.

\section{Potensi Pengembangan Produk Substitusi}

Untuk produk substitusi di industri otomotif, relatif tidak ada substitusi lain selain motor dan juga angkutan umum yang harganya relatif lebih murah. Untuk mengantisipasi hal tersebut, perusahaan melihat keinginan pasar ternyata mobil yang dapat mengangkut banyak orang dengan harga yang relatif murah, terlihat dari Avanza dan Xenia yang menduduki peringkat 1 dan 2 mobil terlaris beberapa tahun terakhir ini. Untuk itu, Nissan telah mengantisipasinya dengan mengeluarkan mobil Grand Livina yang merupakan jenis mobil yang menyumbangkan $60 \%$ dari total pendapatan Nissan di Indonesia. Untuk ke depannya, Nissan juga akan memproduksi mobil dengan harga setara dengan Grand Livina, untuk memenuhi keinginan konsumen yang ternyata banyak di segmen pasar tersebut. Selain itu, Nissan pun akan mengeluarkan minimal 1 jenis mobil setiap tahunnya.

\section{Kekuatan Tawar-Menawar Penjual/Pemasok}

Untuk memperkuat posisi di pasar otomotif nasional, Nissan akan memproduksi minimal 6 jenis mobil secara lokal di Indonesia. Keenam mobil yang akan diproduksi lokal di Indonesia adalah Livina, Serena, X-Trail, March, Juke, dan ada satu lagi masih dirahasiakan hingga kini. Untuk mewujudkan hal tersebut, kapasitas produksi pabrik akan ditingkatkan dari 50.000 menjadi 100.000 unit per tahun hingga 2013. Selain itu, nilai investasinya pun akan ditambahkan senilai 20 juta dollar AS. Selain itu, penggunaan komponen lokal hingga 60\% dalam waktu dekat ini. Untuk itu, sebuah pusat riset dan pengembangan akan dibangun di Indonesia pada tahun 2011 sebagai upaya menjamin kualitas produk yang dihasilkan di tanah air. Berdasarkan data gabungan industri kendaraan bermotor Indonesia (Gaikindo) menyebutkan sekitar 12 ribu dari total 18 ribu penjualan Nissan selama 6 bulan pertama 2010 datang dari keluarga Nissan Livina. Nissan optimistis karena pasar di Indonesia berkembang pesat sehingga diharapkan Indonesia dapat menjadi eksportir bersama India dan Thailand. 
Di India, kapasitas produksi Nissan mencapai 400 ribu unit per tahun, sedangkan di Thailand sebanyak 200 ribu unit per tahun. Selain itu, sudah adanya komitmen pemerintah Indonesia untuk menekan biaya logistik yang merupakan salah satu kendala utama karena biaya logistik mencapai 4 kali lipat biaya manufaktur. Biaya logistik itu mencakup transportasi dari pabrik ke pelabuhan dan barang-barang dari pemasok ke pabrik. Jika fasilitas Indonesia diperbaiki dan biaya lebih murah, maka pasti akan berkembang lebih cepat lagi. Indonesia berpeluang untuk menyamai Thailand dalam industri otomotif. Ini terlihat dari tekad pemerintah melalui Kementerian Perindustrian (Kemenperin) selaku pembina industri nasional untuk sementara menyamai basis industri komponen. Thailand unggul dalam bidang otomotif dikarenakan memiliki industri komponen yang kuat sehingga lebih kompetitif dari segi biaya produksi. Meskipun belum bisa menyamai dalam perakitan, akan tetapi apabila semua instansi terkait ikut mendukung, maka tidak akan sulit bagi industri komponen di tanah air untuk berada di barisan paling depan di ASEAN.

\section{Kekuatan Tawar-Menawar Pembeli/Konsumen}

Untuk menghadapi kekuatan tawar-menawar konsumen, Nissan selalu memberikan kualitas terbaik, dan juga Nissan selalu melakukan survei pasar untuk mengetahui keinginan konsumen. Berdasarkan survei yang dilakukan selama IIMS, peminat Nissan March yang akan diproduksi November dan akan dipasarkan akhir tahun 2010 ini atau awal tahun depan, dilakukan survei terhadap 300 responden (Antara News, Indonesia). Dari data tersebut, dapat diketahui bahwa ternyata warna pilihan yang paling diminati konsumen adalah warna putih sebesar 33\%, hitam 27\%, dan silver 18\%. Dari sisi jenis mesin, sebanyak $75 \%$ konsumen lebih menyukai mobil automatic. Penjualan Nissan tahun 2009 mencapai 21.440 unit.

\section{SIMPULAN}

Saat ini penjualan produk Nissan dalam tren yang terus meningkat. Untuk kedepannya, Nissan mempunyai peluang yang sangat besar untuk dapat terus meningkatkan pangsa pasarnya di Indonesia, terlihat dari penjualan produk Nissan yang terus meningkat di tahun 2010 ini. Selain itu, dari sisi perusahaannya sendiri, Nissan mempunyai strategi yang cukup baik dengan selalu berinovasi menciptakan model baru setiap tahun dan juga selalu melakukan survey pasar untuk melihat keinginan konsumen. Di sisi produksi, Nissan juga mempunyai peluang yang cukup besar dalam memproduksi di dalam negeri, situasi krisis yang tengah dihadapi Thailand dapat dijadikan sebagai suatu peluang bagi Indonesia untuk lebih maju. Mengingat tahun ini pasar domestik nasional berpotensi menggeser posisi Thailand sebagai pasar mobil yang terbesar di ASEAN hingga 640.000-700.000 unit. Para prinsipal di Jepang sudah menyatakan ketertarikan menjadikan Indonesia sebagai alternatif investasi di ASEAN, dengan catatan harus ada kepastian hukum, kemudahan peraturan dan insentif fiskal. 


\section{DAFTAR PUSTAKA}

Afrianto. (2010). Carlos Ghosn siapkan strategi Nissan di Indonesia, Bisnis Indonesia. Diakses Juni 28, 2010, dari www.Bataviase.co.id.

Aldaba, R.M. (2007). Assessing the competitiveness of the Philippine auto parts industry. Discussion paper series No. 2007-14, November 2007.

Anonim. (2010). Juke dan March Andalan Nissan. Diakses Juli 20, 2010, Antara News Indonesia.

Chau, V.S., and Witcher, B.J. (2008). Dynamic capabilities for strategic team performance management: the case of Nissan, Norwich, UK: University of East Anglia.

David, F. (2009). Strategic management, New Jersey: Pearson Prentice Hall.

Indonesia Autos Report. Business monitor international. Retrieved from www.businessmonitor.com.

Nissan. (2003). Alliance Vision - Destination. Retrieved from www.nissan-global.com, Tokyo: Nissan Motor Company.

Pugliese, T. (2010). ASEAN automotive market review - Management briefing, Just-Auto, March/April 2010, p.1.

Thai the Knot. (2009). Go auto news market insight report, August 5, 2009, No. 494, pg. 18.

Veloso, F., and Kumar, R. (2005). The automotive supply chain global trends and ASEAN perspective. ISSN 1655-5252, ERD working paper series, No. 3, 2005. 